\title{
Clinical and GAA gene mutation analysis in mainland Chinese patients with late-onset Pompe disease: identifying c.2238G >C as the most common mutation
}

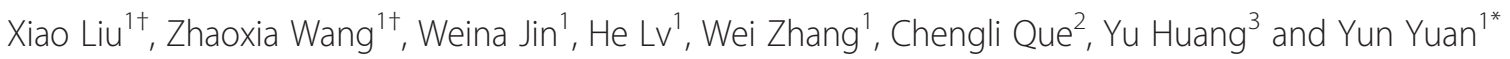

\begin{abstract}
Background: Pompe disease is an autosomal recessive lysosomal glycogen storage disorder that has been reported in different ethnic populations which carry different common mutations of the acid alpha-glucosidase (GAA) gene. The GAA mutation pattern in mainland Chinese patients with late-onset Pompe disease is still not well understood.

Methods: We presented the clinical and genetic characteristics of 27 mainland Chinese late-onset Pompe patients from 24 families.

Results: GAA mutation analysis revealed 26 different mutations, including 10 that were novel. The allelic frequency of c.2238G > C (p.W746C) was found to be $27.08 \%$ in this patient group. Respiratory dysfunction was diagnosed in 10 of 11 patients who underwent pulmonary function evaluation, although only four required ventilator support at night.

Conclusions: Our findings indicate that c.2238G > C (p.W746C) is the most common mutation in mainland Chinese late-onset Pompe patients, as observed in Taiwanese patients. The novel mutations identified in this study expand the genetic spectrum of late-onset Pompe disease, and the prevalence of respiratory dysfunction highlights the importance of monitoring pulmonary function in late-onset Pompe patients.
\end{abstract}

\section{Background}

Pompe disease (glycogen storage disease type II, acid maltase deficiency, OMIM \#232300) is an autosomal recessive lysosomal glycogen storage disorder caused by a deficiency of the lysosomal enzyme acid $\alpha$-glucosidase (GAA). Pompe disease occurs in approximately 1 per 40,000 births [1], and patients are typically classified as early (infantile) or late-onset (childhood/juvenile/adult) according to the age of symptom onset. Patients with classical infantile-onset Pompe disease display a combination of generalized skeletal muscle weakness and cardiac hypertrophy that provoke cardiorespiratory failure and death within the first year of life [2]. Conversely, the

\footnotetext{
*Correspondence: yuanyun2002@sohu.com

${ }^{\dagger}$ Equal contributors

'Department of Neurology, Peking University First Hospital, Beijing 100034, China

Full list of author information is available at the end of the article
}

late-onset form of Pompe disease exhibits a less severe phenotype with progressive proximal skeletal muscle weakness and respiratory muscle involvement. These nonspecific symptoms often make Pompe disease clinically difficult to differentiate from other neuromuscular diseases, but valuable evidence can be provided by measurement of decreased GAA activity, observations of vacuoles in muscle fibers on muscle biopsy, and genetic tests of the GAA gene $[3,4]$.

This gene has been mapped to chromosome 17q25.2q25.3; it contains 20 exons and the first amino acid is encoded by exon 2. Pathogenic sequence variations in GAA can lead to complete or partial loss of lysosomal GAA activity, and a close correlation exists between the functional GAA protein and clinical phenotype: the less residual GAA activity, the earlier the onset and greater the severity of the disease [5,6]. To date, over 400 different mutations have been described [see http://www. 
pompecenter.nl]. Some mutations appear with considerable frequency in distinct ethnic groups. For example, c.-32-13 $\mathrm{T}>\mathrm{G}$ is the most common mutation in Caucasian patients with a frequency as high as 34-47\% [4,7-11]. Conversely, c.1935C > A (p.D645E) and c.2238G > C (p.W746C) are common in Taiwanese patients [12]. Awareness of Pompe disease has been increasing in recent years, and more cases have been reported worldwide [13-15]. However, limited data have been published about mainland Chinese late-onset Pompe patients [16-18]. We herein present the clinical features and GAA mutation pattern of 27 patients from 24 unrelated families with late-onset Pompe disease from mainland China.

\section{Methods}

\section{Subjects}

Twenty-seven patients from 24 unrelated families (Table 1) who were diagnosed with Pompe disease at the Department of Neurology, Peking University First Hospital (Peking, China) from 2003 to 2013, were recruited in this study. None of the patients had consanguineous parents. Their confirmatory diagnosis was based on clinical features, biochemical assay, muscle pathology, and molecular tests. All patients gave their informed consent for this study, and ethical approval for the study was obtained from the health authority ethical committee of Peking University First Hospital.

Clinical data included disease history and physical examination. Eleven patients with the late-onset form of Pompe disease underwent a respiratory function evaluation, including measurement of forced vital capacity (FVC) in a sitting and supine position, forced expiratory volume in one second (FEV1), maximal inspiratory pressure (MIP), maximal expiratory pressure (MEP), and cough peak flow (CPF).

\section{Muscle pathology}

Muscle biopsies were carried out in 19 patients. Muscle specimens were snap frozen in cooled isopentane, and then stored at $-80^{\circ} \mathrm{C}$ until required for analysis. Cryostat sections were prepared and stained according to standard procedures with hematoxylin eosin, modified Gomori trichrome, periodic acid-Schiff (PAS), oil red O, adenosine triphosphatase, nicotinamide adenine dinucleotide-tetrazolium reductase (NADH-TR), succinate dehydrogenase, cytochrome $\mathrm{c}$ oxidase (COX), and non-specific esterase.

\section{Biochemical assays}

In 15 of the 27 patients, GAA enzyme activity in dried blood spots (DBS) was determined with 4- methylumbelliferylalpha-D-glucoside (4-MUG) as the substrate and acarbose as an inhibitor of maltose glucoamylase (MGA) using a fluorometric assay as described [19].

\section{GAA mutation analysis}

GAA mutation screening was performed in all patients. Genomic DNA was extracted from peripheral blood or frozen muscle biopsy specimens using standard procedures. All GAA exons and intron/exon boundaries were amplified by PCR, and then PCR products were purified and sequenced using an $\mathrm{ABI} 3730 \mathrm{XL}$ automatic sequencing machine (Applied Biosystems, Life Technologies, Carlsbad, CA, USA). Sequences were compared with the GAA reference DNA sequence (GenBank Accession: NM_000152) to identify pathogenic mutations. The cDNA was numbered with +1 corresponding to the $\mathrm{A}$ of the ATG translation initiation codon and with codon 1 as the initiation codon. The pathogenic nature of novel missense mutations was verified by direct sequencing of 100 unrelated healthy individuals. Additionally, GAA mutation analysis was performed in the parents of seven Pompe patients after obtaining their informed consent. To determine the effect of a possible splice-site mutation (c.1551+ 3_c.1551 +6delAAGT) in intron 9, we extracted Total RNA from Patient 20 's muscle samples, and amplified the whole cDNA by reverse transcriptase-polymerase chain reaction (RT-PCR) using the SuperScript III First-Strand DNA Synthesis kit (Invitrogen, Carlsbad, CA, USA). A region encompassing exons 9-10 was amplified using primers G9-10 F: 5' - CGTTCAACAAGGATGGCTTC-3' and G9-10R: 5'-GTGGGTTCTCCAGCTCATTG-3'. PCR products were analyzed by agarose electrophoresis.

\section{Results}

\section{Clinical manifestations of patients}

The clinical features of the 27 patients ( 9 male, 18 female) are summarized in Table 1. Patients 23 and 24 are a sibling pair, and patients 25,26 , and 27 are also siblings.

In present study, the patients' age at onset ranged from $1.2-32$ years with a median age of 21 years. Twenty-one (77.8\%) complained of muscle weakness as their initial and main symptom. All patients had skeletal muscle weakness predominantly affecting the proximal extremities. Four patients reported that respiratory insufficiency was the initial clinical symptom that prompted them to seek medical help. Two patients presented with hyperCKemia as their initial symptoms. The median age at diagnosis was 22 years (range, 3-35 years). Eighteen patients had their diagnosis confirmed initially by muscle pathology, followed by mutation detection and/or GAA activity assay. Six patients were diagnosed by a combination of GAA activity assay and genetic analysis, and three patients by genetic analysis alone.

With disease progression, 15 late-onset patients suffered respiratory dysfunction, and persistent or intermittent assisted respiration was required in 10 of these (Table 1). The median serum creatine kinase (CK) level was $700 \mathrm{IU} /$ L (range, 79.0-2,391.6 IU/L). The echocardiography 
Table 1 Clinical, enzymatic, and molecular information of $\mathbf{2 7}$ Chinese patients with late-onset Pompe disease

\begin{tabular}{|c|c|c|c|c|c|c|c|c|c|c|c|}
\hline \multirow[t]{2}{*}{ No. } & \multirow{2}{*}{$\begin{array}{l}\text { Gender/ } \\
\text { Age }\end{array}$} & \multirow{2}{*}{$\begin{array}{l}\text { Age of } \\
\text { onset(years) }\end{array}$} & \multirow{2}{*}{$\begin{array}{l}\text { Age of } \\
\text { diagnosis } \\
\text { (years) }\end{array}$} & \multirow[t]{2}{*}{ Initial symptoms } & \multirow{2}{*}{$\begin{array}{l}\text { Family } \\
\text { history }\end{array}$} & \multirow{2}{*}{$\begin{array}{l}\text { CK } \\
\text { (IU/L) }\end{array}$} & \multirow{2}{*}{$\begin{array}{l}\text { Muscle } \\
\text { pathology }\end{array}$} & \multirow{2}{*}{$\begin{array}{l}\text { lymphocyteGAA } \\
\text { activity (pmol/ } \\
\text { punch/hr) })^{1}\end{array}$} & \multicolumn{2}{|l|}{ GAA gene mutation } & \multirow{2}{*}{$\begin{array}{l}\text { Requirement } \\
\text { of ventilator } \\
\text { support }\end{array}$} \\
\hline & & & & & & & & & Allele1 & Allele2 & \\
\hline 1 & $F / 3$ & 1.2 & 3 & Muscle weakness & No & 568 & $\begin{array}{l}\text { Vacuolar } \\
\text { myopathy }\end{array}$ & ND & c. $503 \mathrm{G}>\mathrm{A}$ & $c .2237 G>A$ & Yes \\
\hline 2 & $F / 3.5$ & 2 & 3.5 & $\begin{array}{l}\text { Muscle weakness and adynamia in } \\
\text { swallowing }\end{array}$ & No & 700 & $\begin{array}{l}\text { Vacuolar } \\
\text { myopathy }\end{array}$ & ND & C. $503 G>C$ & c. $1082 C>T$ & No \\
\hline 3 & $M / 14$ & 8 & 14 & Muscle weakness & No & 907 & $\begin{array}{l}\text { Vacuolar } \\
\text { myopathy }\end{array}$ & ND & c.796C > T & c.1309C > T & No \\
\hline 4 & $F / 22$ & 5 & 22 & Muscle weakness & No & 1101 & $\begin{array}{l}\text { Vacuolar } \\
\text { myopathy }\end{array}$ & ND & c.1562A > T & c. $1781 G>A$ & No \\
\hline 5 & $\mathrm{M} / 30$ & 10 & 30 & Muscle weakness & No & 642 & $\begin{array}{l}\text { Vacuolar } \\
\text { myopathy }\end{array}$ & ND & c. $503 \mathrm{G}>\mathrm{A}$ & c. $2237 \mathrm{G}>\mathrm{A}$ & No \\
\hline 6 & $F / 23$ & 21 & 21 & Limb girdle weakness & No & 1047 & ND & 0 & c.1355delC & c. $2238 G>C$ & Yes \\
\hline 7 & $M / 17$ & 17 & 17 & Muscle weakness & No & 1413 & ND & ND & c. $2238 G>C$ & c. $2238 G>C$ & No \\
\hline 8 & $M / 12$ & 12 & 12 & Muscle weakness & No & 1365 & $\begin{array}{l}\text { Vacuolar } \\
\text { myopathy }\end{array}$ & 3.15 & $c .871 C>T$ & c. $2238 \mathrm{G}>\mathrm{C}$ & No \\
\hline 9 & $M / 23$ & 21 & 21 & Limb girdle weakness & No & 2391.6 & ND & 2.25 & c. $323 G>A$ & c. $2014 C>T$ & No \\
\hline 10 & $M / 14$ & 6 & 13 & Respiratory insufficiency & No & 637 & $\begin{array}{l}\text { Vacuolar } \\
\text { myopathy }\end{array}$ & 3.96 & c.1935C > A & c. $2238 G>C$ & No \\
\hline 11 & $F / 17$ & 3 & 4 & High level of serum CK & No & 1227 & $\begin{array}{l}\text { Vacuolar } \\
\text { myopathy }\end{array}$ & 0.25 & c. $2238 G>C$ & $c .2662 \mathrm{G}>\mathrm{T}$ & No \\
\hline 12 & $F / 15$ & 10 & 13 & Limb girdle weakness & No & ND & $\begin{array}{l}\text { Vacuolar } \\
\text { Myopathy }\end{array}$ & 4.04 & c. $2238 G>C$ & & No \\
\hline 13 & $F / 24$ & 12 & 20 & Muscle weakness & No & 1200 & $\begin{array}{l}\text { Vacuolar } \\
\text { myopathy }\end{array}$ & 1.15 & c.1561G > A & $c .2161 G>T$ & Yes \\
\hline 14 & $F / 25$ & 15 & 23 & Muscle weakness & No & 662.6 & $\begin{array}{l}\text { Vacuolar } \\
\text { myopathy }\end{array}$ & ND & c.1315_1317delATG & c. $2238 G>C$ & Yes \\
\hline 15 & $F / 35$ & 29 & 35 & Muscle weakness & No & 406 & $\begin{array}{l}\text { Vacuolar } \\
\text { myopathy }\end{array}$ & 3.54 & c. $1082 C>T$ & & No \\
\hline 16 & $F / 33$ & 32 & 32 & High level of serum CK & No & 927 & $\begin{array}{l}\text { Vacuolar } \\
\text { myopathy }\end{array}$ & 3.32 & c. $-32-13 \mathrm{~T}>\mathrm{G}$ & c. $2662 \mathrm{G}>\mathrm{T}$ & No \\
\hline 17 & $M / 32$ & 28 & 32 & Muscle weakness & No & 117 & $\begin{array}{l}\text { Vacuolar } \\
\text { myopathy }\end{array}$ & 8.05 & $c .1634 C>T$ & c. $2662 \mathrm{G}>\mathrm{T}$ & No \\
\hline 18 & $F / 35$ & 25 & 25 & Sleep disordered breathing & No & 79 & $\begin{array}{l}\text { Vacuolar } \\
\text { myopathy }\end{array}$ & ND & c.2238G > C & c.2431delC & Yes \\
\hline 19 & $M / 20$ & 19 & 20 & Limb girdle weakness & No & 800 & $\begin{array}{l}\text { Vacuolar } \\
\text { myopathy }\end{array}$ & 3.46 & c.1634C > T & c.1993G > A & Yes \\
\hline 20 & $F / 23$ & 23 & 23 & Respiratory insufficiency & No & 345 & $\begin{array}{l}\text { Vacuolar } \\
\text { myopathy }\end{array}$ & 5.98 & $\begin{array}{l}\text { c. } 1551+\text { 3_c. } 1551+ \\
\text { 6delAAGT }\end{array}$ & c. $2238 \mathrm{G}>\mathrm{C}$ & Yes \\
\hline
\end{tabular}


Table 1 Clinical, enzymatic, and molecular information of 27 Chinese patients with late-onset Pompe disease (Continued)

\begin{tabular}{|c|c|c|c|c|c|c|c|c|c|c|c|}
\hline 21 & $\mathrm{~F} / 32$ & 23 & 30 & Muscle weakness & No & 139 & $\begin{array}{l}\text { Vacuolar } \\
\text { myopathy }\end{array}$ & 1.1 & c. $1935 C>A$ & c. $2238 \mathrm{G}>\mathrm{C}$ & Yes \\
\hline 22 & $F / 14$ & 9 & 14 & Limb girdle weakness & No & 970 & $\begin{array}{l}\text { Vacuolar } \\
\text { myopathy }\end{array}$ & ND & $c .2446 G>A$ & c. $2662 \mathrm{G}>\mathrm{T}$ & No \\
\hline $23^{2}$ & $\mathrm{~F} / 30$ & 24 & 30 & Muscle weakness & Yes & 563 & ND & ND & c.1396delG & c. $2238 G>C$ & No \\
\hline $24^{2}$ & $F / 28$ & 23 & 28 & Muscle weakness & Yes & 746 & ND & ND & c.1396delG & c. $2238 G>C$ & No \\
\hline $25^{3}$ & $M / 24$ & 16 & 22 & respiratory insufficiency and fatigue & Yes & 790 & ND & 0 & c. $241 C>T$ & c.2238G >C & Yes \\
\hline $26^{3}$ & $F / 31$ & 12 & 28 & Muscle weakness & Yes & ND & ND & 0.6 & c. $241 C>T$ & c. $2238 G>C$ & No \\
\hline $27^{3}$ & $F / 29$ & 27 & 27 & Limb girdle and muscle weakness & Yes & 303 & ND & 0.44 & c. $241 C>T$ & $c .2238 G>C$ & Yes \\
\hline
\end{tabular}

1 The median activities of 19 normal controls and 14 carriers were 36.37 (range, 15.16-297.86) and 24.77 (range, 11.84-43.97) pmol/punch/hour, respectively. 2 patient 23 and 24 are siblings; 3 patient 25,26, 27 are siblings. 

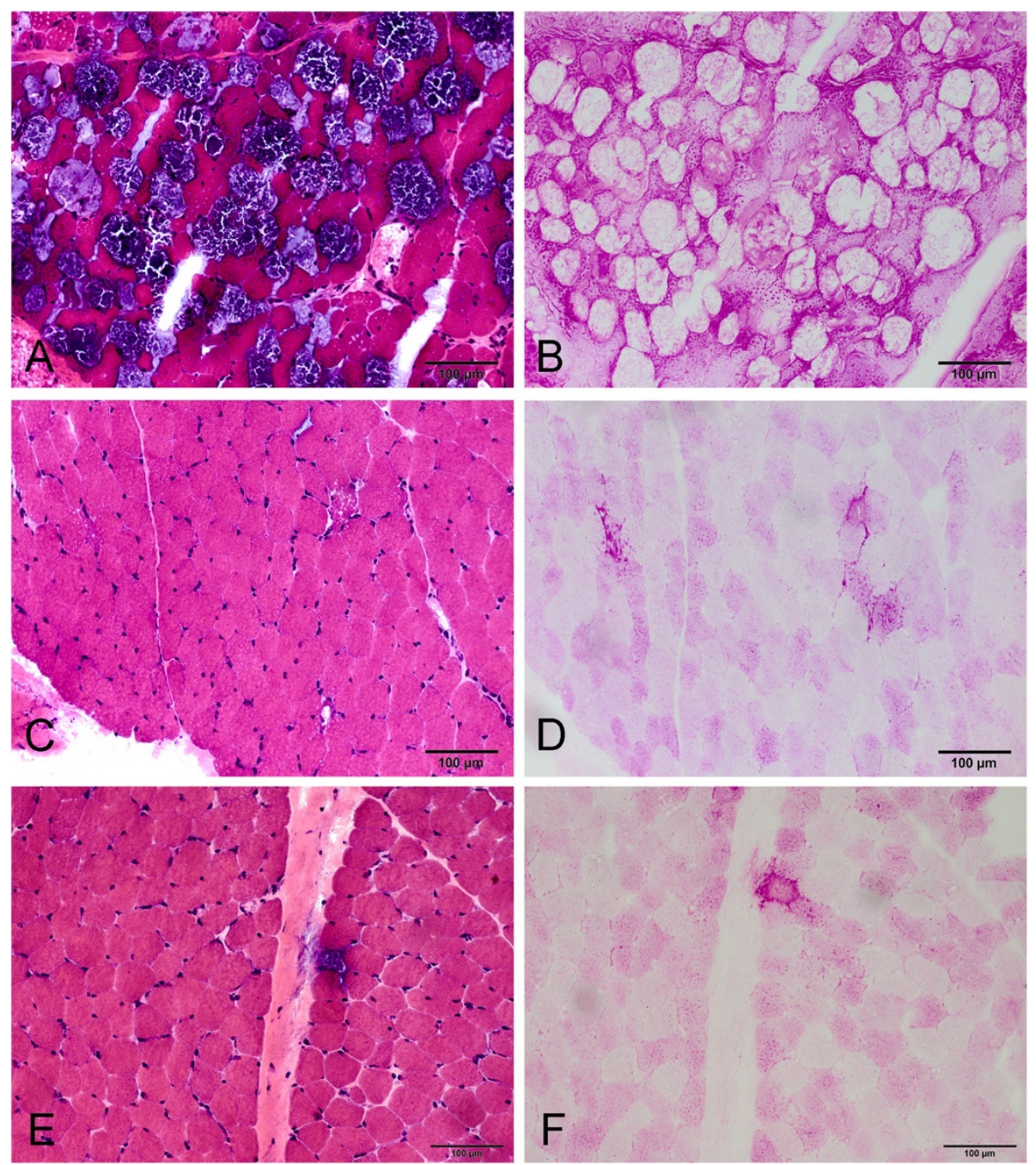

Figure 1 Myopathological changes in Patient 2 (A and B), Patient 12 (C and D) and Patient 22 (E and F). H\&E staining shows extensive vacuolation in many fibers in Patient 2 (A), but only a few vacuolar fibers in Patient 12 (C) and Patient 22 (E). Vacuolar fibers stained positive for glycogen with PAS (B, D and F).

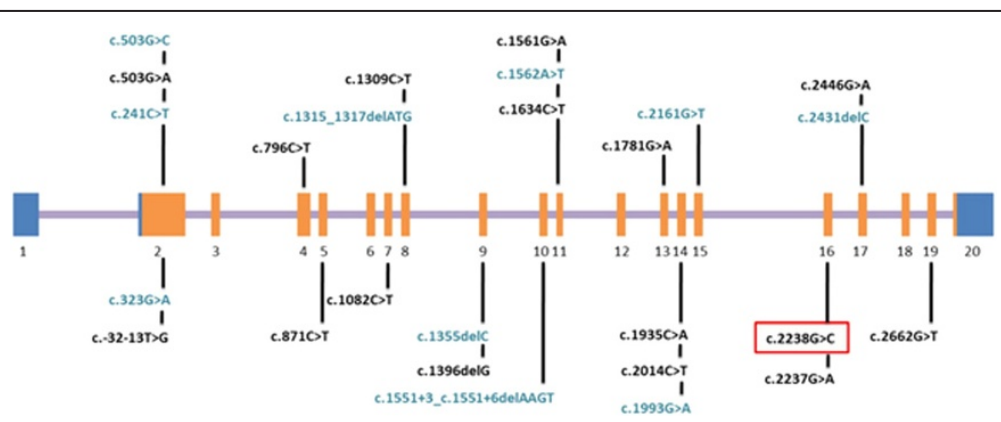

Figure 2 GAA mutation spectrums in 27 Chinese late-onset Pompe patients. All described mutations are shown above (blue, UTR; purple, introns; orange, exons). 
performed in four late-onset patients showed no significant abnormality. Respiratory function evaluation in 11 late-onset patients (four requiring respiratory assistance at night) revealed that $90.90 \%$ (10/11) were abnormal. Further detailed clinical information has been reported by us previously [17].

\section{Muscle pathology}

All 19 patients who underwent muscle biopsy showed muscle fibers with vacuoles that stained positive for glycogen in a PAS stain. The proportion of vacuolar fibers was various among all the patients (Figure 1).

\section{GAA activity assay}

The median GAA activity of 16 patients was $2.70 \mathrm{pmol} /$ punch/hour (range, 0-8.05), while the median activities of 19 normal controls and 14 carriers were 36.37(range, 15.16-297.86) and 24.77 (range, 11.84-43.97) pmol/punch/ hour, respectively.

\section{GAA mutations}

Among the 27 patients recruited in this study there were five sibling pairs from two separate families, so 24 unrelated families are presented. GAA mutation analysis disclosed 21 families with compound heterozygous mutations, one with homozygous mutations, and two with only one heterozygous mutation (Table 1). A total of 26 different mutations were detected in the 24 families (Table 1, Figure 2), including 18 missense mutations, two nonsense mutations, four deletion mutations, and two splice site mutations. Fifteen patients from 12 families carried the c.2238G > C mutation, including 14 compound heterozygotes and one homozygote. The allele frequency of the c.2238G > C mutation in our patients was therefore $27.08 \%$ (13/48). Of the $26 \mathrm{mu}-$ tations, 15 (c.503G > A, c.796C > T, c.871C > T, c.1082C > $\mathrm{T}$, c. $1309 \mathrm{C}>\mathrm{T}$, c. $1561 \mathrm{G}>\mathrm{A}$, c. $1634 \mathrm{C}>\mathrm{T}$, c. $1781 \mathrm{G}>$ A, c. 1935 C > A, с.2014C > T, с.2238G > C, c.2662G > T, c.2237G > A, c.1396delG, and c.-32-13 T> G) have previously been reported as pathogenic, one (c.2446G > A) was reported as non-pathogenic[see http://www.pompecenter. $\mathrm{nl}$, but the other 10 (c.323G > A, c.503G > C, c.1562A > T, c.1993G > A, c. $241 \mathrm{C}>\mathrm{T}$, c. $2161 \mathrm{G}>\mathrm{T}$, c. $1355 \mathrm{delC}, \mathrm{c} .1315$ 1317delATG, c.2431delC, and c.1551+3_c.1551 + 6de AAGT) are novel.

None of the 10 novel mutations were detected in 100 unrelated healthy controls. The c. $241 \mathrm{C}>\mathrm{T}$ and c.2161G > $\mathrm{T}$ mutations lead to a premature stop in protein synthesis, which was assumed to be deleterious since stop codons located upstream of the main stop codon could result in truncated protein. There were four novel small deletions detected, among them c.1551 + 3_c.1551 + 6delAAGT confirmed to cause exon 10 skipping by RT-PCR (Figure 3), c.1355delC, and c.2431delC mutations predicted to cause a frame shift effect, while c.1315_1317delATG predicted to cause in frame deletion. Of the four novel missense mutations, the amino acids mutated in p.Glu521Val (c.1562A > T) and p.Gly665Arg (c.1993G > A) are highly conserved across the examined species (Figure 4), suggesting that they are potentially pathogenic. p.Cys108Tyr (c.323G > A)

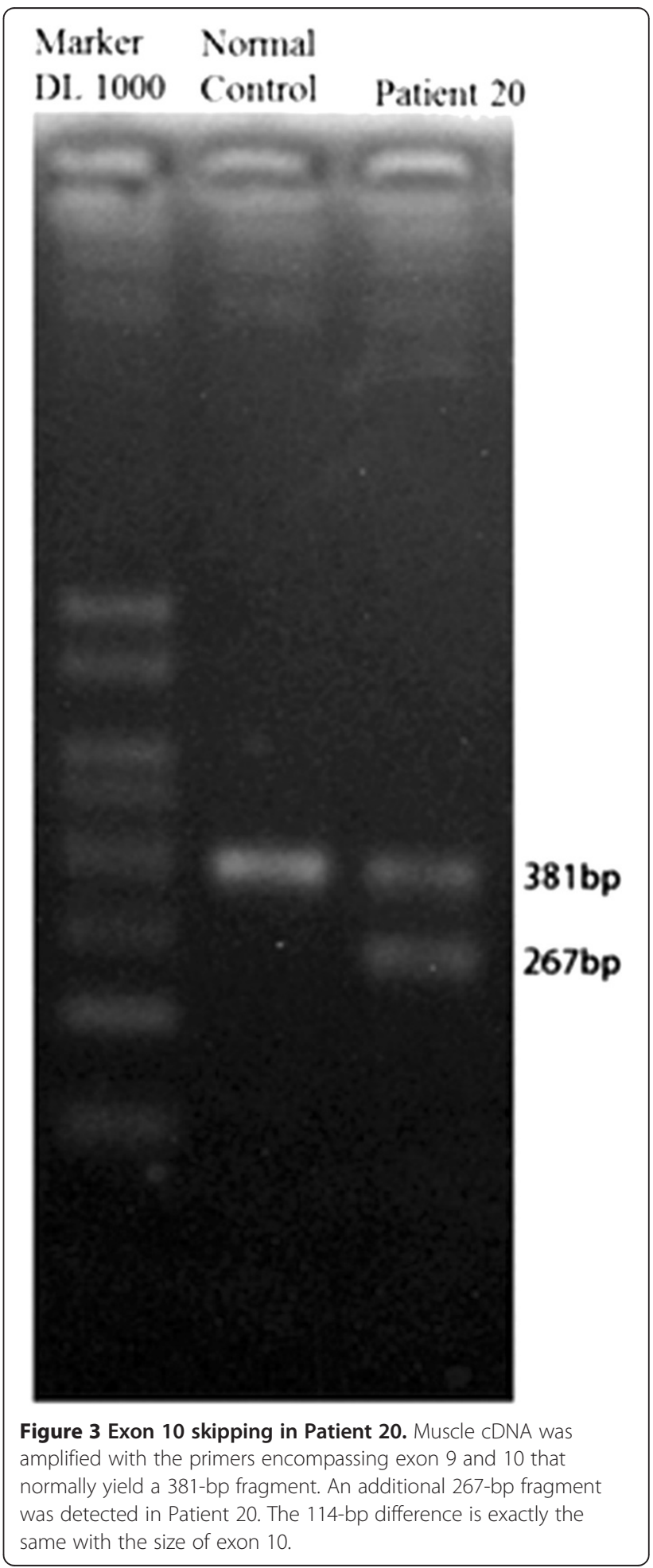




X. crassa
S. pombe
S. pombe
S. pombe
O. sativa
A. thaliana
A. thaliana
D. rerio
G. gallus
X. musculus
R. norvegicus
X. mulatta
H. sapiens
P. troglodytes
B. taurus
C. lupus

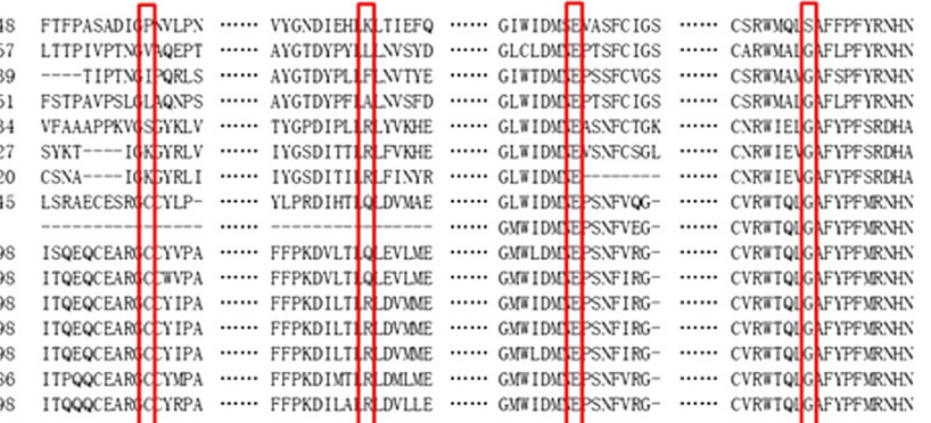

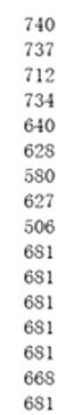

Figure 4 Conservation of four novel missense mutations in different species.

and p.Arg168Pro (c.503G > C), however, were less conserved, indicating that the mutations are more likely to be mild in severity. The healthy parents of patients 11 (c.323G > A; c.2014C > T) and 21 (c.1634C > T; c.1993G > A) were found to carry one heterozygous mutation each that were present in their offspring.

\section{Discussion}

Although Pompe disease is rare, it has been reported in a number of different ethnic populations, such as Caucasian, Taiwanese, Korean and Japanese [4,7-12,20-23]. This study is the largest series of mainland Chinese late-onset Pompe patients, including 27 patients from 24 unrelated families. Our results showed that the majority of our patients (15/ $27,55.56 \%$ ) carried the c. $2238 \mathrm{G}>\mathrm{C}$ mutation of $G A A$, and that the allele frequency of c.2238G $>\mathrm{C}$ was as high as $27.08 \%$, making it the most common mutation in this group. This result is consistent with findings in Taiwanese Pompe patients [12], but different from the common mutation (c.1935C > A) in mainland Chinese infantile-onset group [24].Meanwhile, c.-32-13 T > G, the most common mutation of Caucasian origin with a frequency of $34-79 \%$ $[3,4,7-10]$, was found in only one patient with compound heterozygous mutations in the present study. Other common mutations reported in certain populations, such as c. $1316 \mathrm{~T}>\mathrm{A}$ and c.1857C > G with a frequency of $36.6 \%$ in Korean patients [20], c.1064 $\mathrm{T}>\mathrm{C}$ which is the predominant mutation in Portuguese patients [21], c.1726G > A with a frequency of up to $27.59 \%$ in Japanese patients [22], and the African-American mutation c.2560 C > T [23], were not detected in our patients. Our study therefore further supports the findings that different populations have different mutation hotspots.

As c. $1935 \mathrm{C}>\mathrm{A}$, the other common mutation in Taiwan, was detected in only one patient from our group, and additionally, c.1726 G > A and c.2065G > A pseudodeficiency mutations which are common in Taiwanese, were absent in the present study, this suggests that the spectrum of GAA mutation differs not only between ethnicities but also from region to region in the same population. The absence of c. [2238G > C; $1726 \mathrm{G}>\mathrm{A}$ ] haplotype in our patients raises the possibility that the c.2238G $>\mathrm{C}$ mutation might have a different ancestor in Taiwan and mainland China. Further research involving more patients is needed to confirm this.

The diagnosis of this patients group with late-onset Pompe disease depended on the combination of clinical manifestations, muscle biopsy, blood-based GAA activity assay and GAA gene analysis. The mean age of onset the patients in the current study was $17.41 \pm 8.99$ years, which is younger than a previous investigation of a Caucasian background, and is in keeping with the study in Taiwanese Pompe patients $[3,10]$. The difference in onset age between Chinese and Caucasian patients with Pompe disease may be caused by the prevalence of the c. $2238 \mathrm{G}>\mathrm{C}$ mutation and the low frequency of c.-32-13 T $>\mathrm{G}$ in the present set of patients, as different mutations have different effects on enzyme activity [12]. Muscular weakness was the most common initial symptom in our study, as seen in an earlier work; [25] however, it is noteworthy that respiratory impairment was very common in our late-onset patients, which is in contrast to the study in Germany in which no patients had respiratory symptoms [25].

Dyspnea without limb weakness was the first reported symptom in four of the current patients, while 10/27 (37.0\%) of late-onset patients needed mechanical ventilation within 2.5 years of disease onset. Moreover, in the seven patients without mechanical ventilation, pulmonary function evaluation revealed decreased pulmonary function in six. Together, our data support previous findings that monitoring pulmonary function is essential in lateonset Pompe disease to evaluate the need for mechanical ventilation $[1,26,27]$.

Notably, in 18 of 27 late-onset patients, diagnosis of Pompe disease was confirmed initially by muscle pathology. Although a blood-based assay has been widely recommended as a simple diagnostic method, we still consider muscle biopsy to be a very useful tool as the diagnosis of Pompe disease can be challenging because of its heterogeneous clinical presentation and considerable overlap of 
signs and symptoms found in other neuromuscular diseases $[28,29]$. This is particular important in east Asia, where the high frequency of the p.[G576S;E689K] pseudodeficiency mutation in these ethnic populations can give false positive results of GAA activity. Moreover, it is not uncommon that only one pathogenic heterozygous mutation is detected in coding region of GAA gene in Pompe patients, as in patient 12, 15, and 22 of this group. In such cases, muscle pathology can provide solid evidence for disease diagnosis (Figure 1, Table 1). However, it should mentioned that the muscle biopsy still has its limitation in diagnosing Pompe disease due to the heterogeneity of muscle involvement, especially in patients with late onset Pompe disease [30].

\section{Conclusions}

Our findings indicate that c.2238G > C (p.W746C) is the most common mutation in mainland Chinese late-onset Pompe patients, as observed in Taiwanese patients. The novel mutations identified in this study expand the genetic spectrum of late-onset Pompe disease, and the prevalence of respiratory dysfunction highlights the importance of monitoring pulmonary function in late-onset Pompe patients.

\section{Competing interests}

The authors declare that they have no competing interests.

\section{Authors' contributions}

$\mathrm{XL}$ carried out the molecular genetic studies, participated in the sequence alignment and drafted the manuscript, as well as ZW. WJ carried out the patients' history taking and data analysis. HL participated in the sequence alignment. WZ participated in the history taking. CQ carried out the respiratory function examination of the patients. YH participated in the GAA activity assay. YY conceived of the study, and participated in its design and coordination. All authors read and approved the final manuscript.

\section{Acknowledgements}

This study was supported by the Ministry of Science and Technology of China (No.2011ZX09307-001-07) and a research grant from Genzyme, A Sanofi Company in Pompe Registry.

\section{Author details}

${ }^{1}$ Department of Neurology, Peking University First Hospital, Beijing 100034, China. ${ }^{2}$ Respiratory Department of Internal Medicine, Peking University First Hospital, Beijing 100034, China. ${ }^{3}$ Department of Medical Genetics, School of Basic Medical Sciences, Peking University Health Science Center, Beijing 100191, China

Received: 12 April 2014 Accepted: 11 December 2014

Published online: 20 December 2014

\section{References}

1. Fuller DD, EIMallah MK, Smith BK, Corti M, Lawson LA, Falk DJ, Byrne BJ: The respiratory neuromuscular system in Pompe disease. Respir Respir Physiol Neurobiol 2013, 189:241-249.

2. Ansong AK, Li JS, Nozik-Grayck E, Ing R, Kravitz RM, Idriss SF, Kanter RJ, Rice H, Chen YT, Kishnani PS: Electrocardiographic response to enzyme replacement therapy for Pompe disease. Genet Med 2006, 8:297-301.

3. Müller-Felber W, Horvath R, Gempel K, Podskarbi T, Shin Y, Pongratz D, Walter MC, Baethmann M, Schlotter-Weigel B, Lochmüller H, Schoser B: Late onset Pompe disease: clinical and neurophysiological spectrum of 38 patients including long-term follow-up in 18 patients. Neuromuscul Disord 2007, 17:698-706.
4. Laforêt P, Nicolino M, Eymard PB, Puech JP, Caillaud C, Poenaru L, Fardeau M: Juvenile and adult-onset acid maltase deficiency in France: genotypephenotype correlation. Neurology 2000, 55:1122-1128.

5. Kroos M, Hoogeveen-Westerveld M, van der Ploeg A, Reuser AJ: The genotypephenotype correlation in Pompe disease. Am J Med Genet C: Semin Med Genet 2012, 160C:59-68.

6. Raben N, Plotz P, Byrne BJ: Acid alpha-glucosidase deficiency (glycogenosis type II, Pompe disease). Curr Mol Med 2002, 2:145-166.

7. Kroos MA, Van der Kraan M, Van Diggelen OP, Kleijer WJ, Reuser AJ, Van den Boogaard MJ, Ausems MG, van Amstel HK P, Poenaru L, Nicolino M: Glycogen storage disease type II: frequency of three common mutant alleles and their associated clinical phenotypes studied in 121 patients. J Med Genet 1995, 32:836-837.

8. Montalvo AL, Bembi B, Donnarumma M, Filocamo M, Parenti G, Rossi M, Merlini L, Buratti E, De Filippi P, Dardis A, Stroppiano M, Ciana G, Pittis MG: Mutation profile of the GAA gene in 40 Italian patients with late onset glycogen storage disease type II. Hum Mutat 2006, 27:999-1006.

9. Gort L, Coll MJ, Chabás A: Glycogen storage disease type II in Spanish patients: high frequency of c.1076-1GC mutation. Mol Genet Metab 2007, 92:183-187.

10. Joshi PR, Gläser D, Schmidt S, Vorgerd M, Winterholler M, Eger K, Zierz S, Deschauer M: Molecular diagnosis of German patients with late-onset glycogen storage disease type II. J Inherit Metab Dis 2008, 31(Suppl 2):261-265.

11. Huie ML, Chen AS, Tsujino S, Shanske S, DiMauro S, Engel AG, Hirschhorn R: Aberrant splicing in adult onset glycogen storage disease type II (GSDII): molecular identification of an IVS1 (-13T-->G) mutation in a majority of patients and a novel IVS10 (+1GT-->CT) mutation. Hum Mol Genet 1994, 3:2231-2236.

12. Yang CC, Chien YH, Lee NC, Chiang SC, Lin SP, Kuo YT, Chen SS, Jong YJ, Hwu WL: Rapid progressive course of later-onset Pompe disease in Chinese patients. Mol Genet Metab 2011, 104:284-288.

13. Wens SC, van Gelder CM, Kruijshaar ME, de Vries JM, van der Beek NA, Reuser AJ, van Doorn PA, van der Ploeg AT, Brusse E: Phenotypical variation within 22 families with Pompe disease. Orphanet J Rare Dis 2013, 8:182.

14. Hanisch F, Rahne T, Plontke SK: Prevalence of hearing loss in patients with late-onset Pompe disease: Audiological and otological consequences. Int J Audiol 2013, 52:816-823.

15. Remiche G, Ronchi D, Magri F, Lamperti C, Bordoni A, Moggio M, Bresolin N, Comi GP: Extended phenotype description and new molecular findings in late onset glycogen storage disease type II: a northern Italy population study and review of the literature. J Neurol 2014, 261:83-97.

16. Liu Q, Zhao J, Wang ZX, Zhang W, Yuan Y: Clinical features and acid alpha-glucosidase gene mutation in 7 Chinese patients with glycogen storage disease type II. Zhonghua Yi Xue Za Zhi 2013, 93:1981-1985. Chinese.

17. Jin W, Que C, Tang H, Huang Y, Wang Z, Liu X, Lv H, Zhang W, Yuan Y: Clinical study of respiratory function in patients with late-onset glycogen storage disease type II. Chinese J Contemp Neurol Neurosurg 2014, 14:399-404. Chinese.

18. Yang J, Cao J, Liu Z, Zhan Y, Liang Y, Mo G, Li Y, Sun Y, Li M, Li J, Zhang C: Clinical features and genetic analysis of 7 patients with late-onset glycogen storage disease type II. Chinese J Contemp Neurol Neurosurg 2014, 14:405-410. Chinese.

19. Kallwass H, Carr C, Gerrein J, Titlow M, Pomponio R, Bali D, Dai J, Kishnani P, Skrinar A, Corzo D, Keutzer J: Rapid diagnosis of late-onset Pompe disease by fluorometric assay of alpha-glucosidase activities in dried blood spots. Mol Genet Metab 2007, 90:449-452.

20. Park HD, Lee DH, Choi TY, Lee YK, Lee SY, Kim JW, Ki CS, Lee YW: Three patients with glycogen storage disease type II and the mutational spectrum of GAA in Korean patients. Ann Clin Lab Sci 2013, 43:311-316.

21. Loureiro Neves F, Garcia PC, Madureira N, Araújo H, Rodrigues F, Estêvão MH, Lacerda L, Diogo Matos LM: Juvenile pompe disease: retrospective clinical study. Acta Med Port 2013, 26:361-370.

22. Oda E, Tanaka T, Migita O, Kosuga M, Fukushi M, Okumiya T, Osawa M, Okuyama T: Newborn screening for Pompe disease in Japan. Mol Genet Metab 2011, 104:560-565.

23. Becker JA, Vlach J, Raben N, Nagaraju K, Adams EM, Hermans MM, Reuser AJ, Brooks SS, Tifft CJ, Hirschhorn R, Huie ML, Nicolino M, Plotz PH: The African origin of the common mutation in African American patients with glycogen-storage disease type II. Am J Hum Genet 1998, 62:991-994

24. Fu L, Qiu W, Yu Y, Guo Y, Zhao P, Zhang X, Liu C, Li F, Huang H, Huang M, Chen S: Clinical and molecular genetic study of infantile-onset Pompe 
disease in Chinese patients: identification of 6 novel mutations. Gene 2014, 535:53-59.

25. Herzog A, Hartung R, Reuser AJ, Hermanns P, Runz H, Karabul N, Gökce S, Pohlenz J, Kampmann C, Lampe C, Beck M, Mengel E: A cross-sectional single-centre study on the spectrum of Pompe disease, German patients: molecular analysis of the GAA gene, manifestation and genotypephenotype correlations. Orphanet J Rare Dis 2012, 7:35.

26. Gaeta M, Barca E, Ruggeri P, Minutoli F, Rodolico C, Mazziotti S, Milardi D, Musumeci O, Toscano A: Late-onset Pompe disease (LOPD): correlations between respiratory muscles $\mathrm{CT}$ and MRI features and pulmonary function. Mol Genet Metab 2013, 110:290-296.

27. Schneider I, Hanisch F, Müller T, Schmidt B, Zierz S: Respiratory function in late-onset Pompe disease patients receiving long-term enzyme replacement therapy for more than 48 months. Wien Med Wochenschr 2013, 163:40-44.

28. Preisler N, Lukacs Z, Vinge L, Madsen KL, Husu E, Hansen RS, Duno M, Andersen $\mathrm{H}$, Laub M, Vissing J: Late-onset Pompe disease is prevalent in unclassified limb-girdle muscular dystrophies. Mol Genet Metab 2013, 110:287-289.

29. Vissing J, Lukacs Z, Straub V: Diagnosis of Pompe disease: muscle biopsy vs blood-based assays. JAMA Neurol 2013, 70:923-927.

30. Kishnani PS, Amartino HM, Lindberg C, Miller TM, Wilson A, Keutzer J: Methods of diagnosis of patients with Pompe disease: Data from the Pompe Registry. Mol Genet Metab 2014, 113:84-91.

\section{Submit your next manuscript to BioMed Central and take full advantage of:}

- Convenient online submission

- Thorough peer review

- No space constraints or color figure charges

- Immediate publication on acceptance

- Inclusion in PubMed, CAS, Scopus and Google Scholar

- Research which is freely available for redistribution 